\title{
ホウ酸ーメタノール溶液含浸処理スギ材 一ホウ素の化学的挙動と分布に関するラマン分光学的研究一
}

\author{
山内繁*, 土居修 -*
}

Japanese cedar treated with methanolic boric acid solutions

-A Raman spectroscopic study of chemical behavior and distribution of boron species-

Shigeru YAMAUCHI*, and Shuichi DoI ${ }^{*}$

Chemical behavior and distribution of boron species in Japanese cedar (Cryptomeria japonica D. Don) specimen treated with methanolic boric acid solutions were investigated by means of weight and Raman spectra measurements. After this treatment, weight gain of the specimens was approximately proportional to the boron concentration in the range of $1.8 \times 10^{-1}$ to $1.1 \mathrm{~mol} /$ $\mathrm{dm}^{3}$. From the Raman measurements, it was revealed that the bulk of boron remains in the specimens as $\mathrm{B}(\mathrm{OH})_{3}$, although a small amount of boron was emitted into air during air-drying. These results indicated that the high concentrated methanolic solutions make it possible to impregnate wood with considerably large amounts of boron in comparison with the aqueous solutions. The Raman spectra, however, suggested that boron was extremely concentrated near the surfaces of the air-dried wood specimen.

スギ（Cryptomeria japonica D. Don）辺材に, ホウ酸 $\left(\mathrm{B}(\mathrm{OH})_{3}\right)$-メタノール溶液として注 入されたホウ素の化学的挙動および乾燥後のホウ素の分布について, 重量変化の計測とラマ ン分光法による分析結果に基づき検討を行った。含浸処理後に風乾したスギ辺材試験体は, 本実験で用いた処理溶液の濃度範囲 $\left(1.8 \times 10^{-1} \sim 1.1 \mathrm{~mol} / \mathrm{dm}^{3}\right)$ でホウ素濃度にほぼ比例し て重量が増加していた。ラマン測定から，風乾中に少量のホウ素は揮発性化合物として放散 するが，処理後の試験体では注入されたホウ素の大部分が $\mathrm{B}(\mathrm{OH})_{3}$ として木材中に残ること が明らかになった。これらから，メタノールを溶媒として用いることにより，水溶液よりも 多量のホウ素を容易に木材中に含浸できることが示された。しかし，ラマン測定の結果から， 風乾による溶媒除去法では，ホウ素は試験体表面近傍だけに偏在してしまうことも示唆され た。

* 秋田県立大学 木材高度加工研究所 秋田県能代市字海詠坂11-1

* Institute of Wood Technology, Akita Prefectural University 11-1 Kaieisaka, Noshiro 016-0876, Japan 


\section{1. 緒 言}

世界的にCCA 系木材防腐剂は代替薬剤への転 換が急速に進んでおり，そのひとつにホウ酸また はホウ酸塩を主成分とする保存剤がある。この保 存剤は環境負荷が比較的少なく,70年ほども前か ら注目されていたが1,2), 現在日本において防 腐, 防カビ, 防蟻剤としての実用化はほとんど進 んでいない。この理由のひとつはホウ酸系木材保 存剤が JIS よとに基づく溶脱操作で容易に木材か ら流出しやすいこと，すなわち直接降雨に曝され る場所での使用に適していないことである。した がって, 木材へのホウ素固定化 ${ }^{3-8)}$ や溶脱 ${ }^{9,10)}$ に関 する研究も多数報告されてきているが，低コスト でかり屋外での使用に耐える方法はまだ開発され ていない。この点を踏まえ,われわれはホウ酸系 保存剤の難溶脱化を目指し、多面的なアプローチ を試みている。基礎的な面では特に木材中での木 ウ酸塩化合物の化学的挙動に着目し, これまでに ホウ酸水溶液で処理したスギ（Cryptomeria japonica D. Don）材について主にラマン分光法を用い て検討し，その分析結果を報告してきている ${ }^{11,12) 。 ~}$ 近年, 蒸気圧の高いホウ酸エステルを気体とし て木材へ注入する方法も実用化に向けて研究され ている ${ }^{13,14}$ が,多くはホウ酸系化合物を水溶液とし て含浸させる注入法が用いられている。最も一般 的なホウ素化合物であるホウ酸は，廉価ではある が水への溶解度が高くないため, 通常の方法では 木材への注入量は限定される。そのため, より溶 解度の高いホウ砂 $\left(\mathrm{Na}_{2} \mathrm{~B}_{4} \mathrm{O}_{7} \cdot 10 \mathrm{H}_{2} \mathrm{O}\right)$ などの木 ウ酸塩と組み合わせて用いられることが多いが, アルカリ金属のホウ酸塩は水溶液の $\mathrm{pH}$ を上昇さ せるため使用が制限され，また洒格もホウ酸以上 である。

一方, 水上りも多くのホウ酸を溶解する溶媒を 用いることによっても，ホウ素の注入量を增加さ せることができる。ホウ酸を溶解する有機溶媒に はメタノール，ジオキサン，エチレングリコール などがあり，いずれも親水性である。これらの中 で, メタノールは最も廉価で, 水より多量のホウ 酸を容易に溶解する。また, 沸点も低く, 含浸後 の溶媒除去回収もしやすいと期待される。これら 点から,われわれはメ夕ノ一ルを溶媒として用い,
より高濃度のホウ素を注入することを試みた。ホ ウ酸のメ夕ノールに対する溶解は化学溶解であ り, 溶液中では溶媒であるメタノールと反応して エステルを形成する。実験に用いたメタノール溶 液中ですべてのホウ素がホウ酸トリメチル（B $\left.\left(\mathrm{OCH}_{3}\right)_{3}\right)$ として存在しているかどうかはわか らないが，いずれにしても大部分のホウ素は，水 溶液中とは異なった化学種として存在することは 容易に推定される。

したがって，メタノール溶液を用いた含浸処理 を水溶液と対比して評価するためには，処理後の 木材中でのホウ素の化学的状態拉よび分布に関す る情報を得ることが不可欠であり，ホウ素分析が 担う役割は重要である。しかしながら，ホウ素は 固体状態での分析が難しい元素であり，さらに局 所分析という条件が加われば分析手法はかなり限 定される。そのため, 木材中での木ウ素の化学状 態や分布を調べた研究は，われわれの報告を除い てEPMAを用いた研究があるのみである ${ }^{15 j}$ 。 の点ラマン分光法は, 測定が比較的簡便で非破壊 的測定や局所分析にも適して抢り,さらに, ホウ素 を化合物や化学種一例えば $\mathrm{B}(\mathrm{OH})_{3} や \mathrm{~B}\left(\mathrm{OCH}_{3}\right)_{3}$ 一として識別することができる。また，水の妨害 を受けにくいため木材中のホウ素化合物を検出し やすく, この点では同じ振動分光法の赤外分光法 より優れているといえる。

この研究では, ホウ酸ーメ夕ノール溶液で処理 したスギ材中のホウ素化合物を同定し，さらに分 布に関する情報を得ることを目的とし，ラマンス ペタトルのマッピング測定を行った。本論文では, 重量変化とラマン測定から得られたホウ酸一メ夕 ノール溶液処理スギ材中でのホウ素の挙動に関す る知見を報告し, 水溶液による含浸处理との比較 検討を行う。

\section{2. 実験}

\section{1 試験体}

風乾した 80 年生の秋田県産スギ材の辺材を用い て，二方柾の直方体を作成し試験体として実験を 行った。寸法は $10 \mathrm{~mm}$ (放射方向) $\times 10 \mathrm{~mm}$ (接線方 向) $\times 50 \mathrm{~mm}$ (繊維方向) とした (図 $1 \mathrm{a}$ 参照）。すべ ての試験体は恒温恒湿器内 $\left(25^{\circ} \mathrm{C}, 60 \% \mathrm{RH}\right)$ で恒 量化し,これを基準重量とした。恒量化後, ホウ 


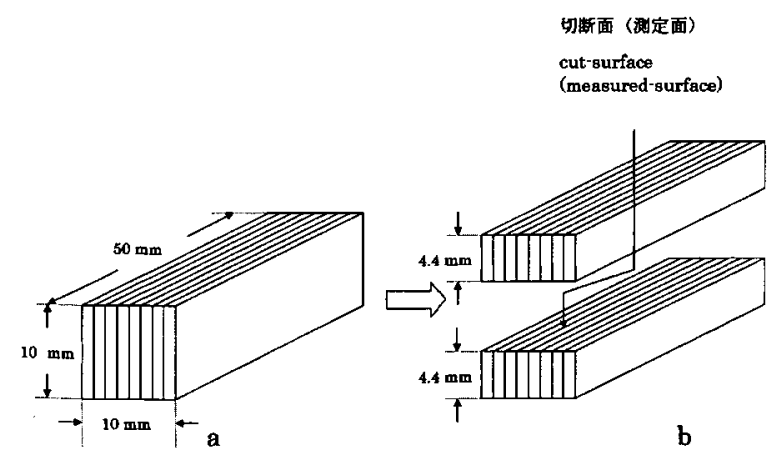

図 1 スギ辺材試験体

(a) 切断前, (b) ラマンスペクトル測定のため の切断後

Fig. 1 Japanese cedar block

(a) before cutting, (b) after cutting for Raman measurement

酸のメタノール溶液および水溶液の含浸处理を行 った。

\section{2 ホウ酸溶液の調製と含浸処理}

ホウ酸およびメタノールは JIS 特級試薬をその まま使用した。ホウ酸トリメチルはJIS一級相当 品をそのままラマン測定に供した。ホウ酸溶液は 既知量のホウ酸を水またはメ夕ノールに溶解し，

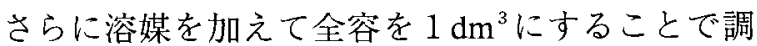
製した。濃度は溶液 $1 \mathrm{dm}^{3}$ 中のホウ素量（モル）, $\mathrm{mol} / \mathrm{dm}^{3}$ で表す。ホウ素濃度の範囲は水溶液が $9.9 \times 10^{-2} \mathrm{~mol} / \mathrm{dm}^{3}$ から $7.3 \times 10^{-1} \mathrm{~mol} / \mathrm{dm}^{3}$, メ夕 ノール溶液が $1.8 \times 10^{-1} \mathrm{~mol} / \mathrm{dm}^{3}$ から $1.1 \mathrm{~mol} / \mathrm{dm}^{3}$ であった。濃度ごとに 3 個の試験体に含浸処理を 行った。内径約 $70 \mathrm{~mm}$ のポリプロピレン製ビーカー に，柾目面（放射断面）が上下に，木口面（横断 面）が鉛直になるように試験体を置き，ステンレ スの重りを載せた後, 約 $0.15 \mathrm{dm}^{3}$ のホウ酸溶液を 注ぎ試験体全体を浸した。その容器を内容量的 2 $\mathrm{dm}^{3}$ の真空デシケー夕に入れ，水流ポンプを用い て室温で減圧含浸を行った。減圧時間は約 5 分間 で，水溶液は50～60mmHgに，メタノール溶液は 100 110mmHg に減圧した。その後，常圧に戻し 60分間そのままの状態を保った。試験体をホウ酸 溶液加ら取り出して, 試験体表面の余㮃な溶液を 濾紙で素早くふきとり，この状態での重量（湿重 量）を測定した。ここまでの溶液調製，含浸操作 はすべて室温 $\left(25 \pm 2{ }^{\circ} \mathrm{C}\right)$ で行った。なお, 各メ タノール溶液について，含浸処理とは別に試験体 がない状態で減圧操作を行い，隇圧による重量減

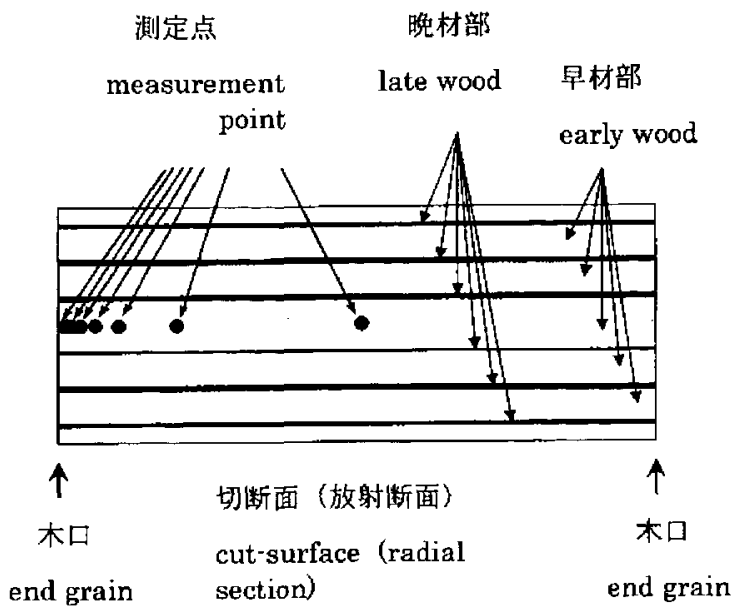

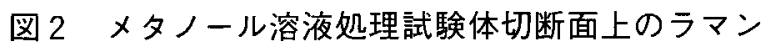
測定点

Fig. 2 Raman measurement points on the cuttingsurface of wood block treated with methanolic boric acid solution

少は1\%末満であることを確認した。

湿重量測定後, 試験体は柾目面を上下にして,

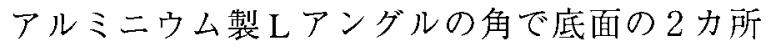
を支持し， $3 \sim 4$ 日間常温常湿 $\left(25 \pm 2{ }^{\circ} \mathrm{C}, 50\right.$ ～ $70 \% \mathrm{RH})$ で風乾した後, さらに含浸前と同一の条 件 $\left(25^{\circ} \mathrm{C}, 60 \% \mathrm{RH}\right)$ で恒量測定した。純メ夕ノー ルおよび純水を用いて同様に減圧含浸処理した試 験体を,重量変化抢よびラマン測定の基準とした。 また，上記とは別に，いくつかの濃度のメタノー ル溶液について, 含浸後の試験体をコニカルビー カー内で風乾する実験も行った。

\section{3 ラマンスペクトル測定}

日本電子製フーリ工変換赤外分光装置 JIR7000 Wにラマン分光ユニットRS-RSU200を接続し, 励起光に対し $180^{\circ}$ 方向の散乱光をアラニンドープ の TGS 検出器で計測することによってラマンス ペクトルを得た。励起光源には $\mathrm{Nd}^{3+}$ : YAGレー ザー $(1,064 \mathrm{~nm})$ を出力約 $200 \mathrm{~mW}$ で用いた。試料 面上のレーザー照射部分の直径は約 $0.5 \mathrm{~mm}$ であ

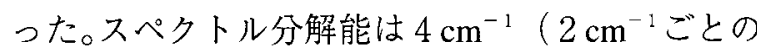
測定)，積算は1000-2000回行った。測定はすべて 室温 $\left(23 \pm 1{ }^{\circ} \mathrm{C}\right)$ で行った。

繊維方向のホウ素分布に関する測定は以下のよ うに行った。含浸処理が完了したスギ試験体を瀻 維方向に沿って柾目面と平行に二等分に切断し, 切断面についてラマンスペクトルを計測した（図 $1 \mathrm{~b}$ および図 2 参照)。測定は早材部についてのみ 
行い，測定面を上方から入射するレーザー光に対 して垂直にし，照射のジオメトリーが一定になる よう試料の位置を調整した。

\section{3. 結果と考察}

\section{1 含浸処理による試験体の重量増加}

同一濃度の水溶液, メ夕ノール溶液で処理した 3 個の試験体は含浸直後の重量増加，すなわち湿 重量と基準重量の差がほぼ一定（標準偏差は平均 值の $3 \%$ 以下）であった。すべてのスギ辺材試験 体は一枚の厚板から切り出して抢り，大きさ，木 取りも同じである。よって，同一濃度の溶液が試 験体全体に均一に浸透したと仮定すれば，その浸 透量はいずれの試験体でも同一であることが期待 される。また，スギ辺材は細胞壁孔の閉塞率も低 く，透過性が高いことが知られている。したがっ て，上記の結果は減圧含浸によって，各試験体に 対し溶液がほほ全体に浸透したこと，すなわち溶 液がほとんどの細胞内腔および細胞間隙を充た し，細胞壁にも一定の割合でしみこんだことを示 していると考えられる。

図 3 に $25^{\circ} \mathrm{C}, 60 \% \mathrm{RH}$ で風乾, 恒量化㣪のスギ辺 材試験体の重量増加と処理に用いたメ夕ノール溶 液のホウ素濃度の関係を示す。以下特に断らない

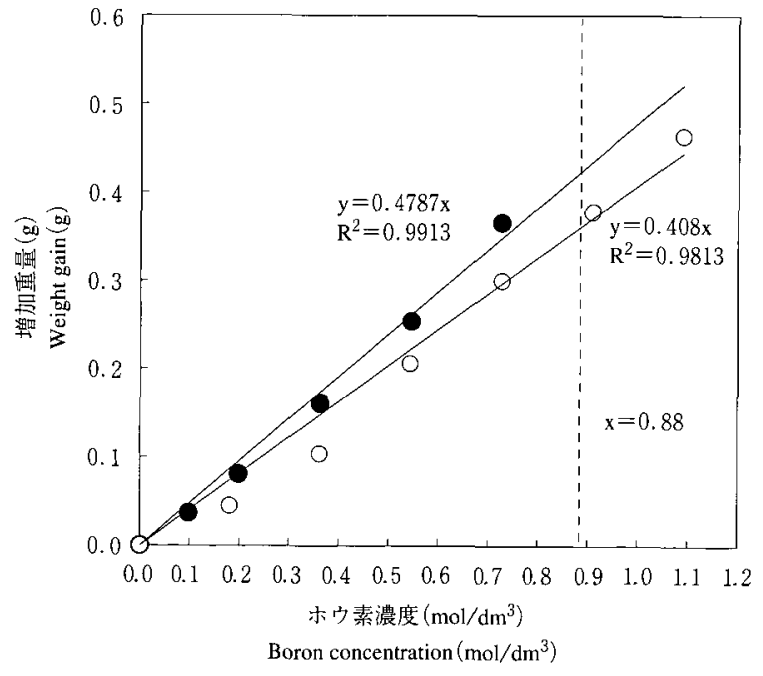

図 3 試験体の重量増加と処理溶液中ホウ素濃度の 相関

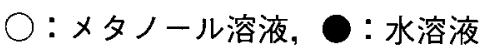

Fig. 3 Relationship between weight gain and concentration of boron $\bigcirc$ : methanolic solution, $P$ :aqueous solution
限り, 重量増加とは風乾，恒量化後の重量増加を 指すこととする。比較のため水溶液処理した試験 体の結果も併せて示したが，重量は処理溶液の木 ウ素濃度に対して直線的に増加している。ホウ酸 の水に対する溶解度は $25^{\circ} \mathrm{C}$ で約 $8.8 \times 10^{-1} \mathrm{~mol} /$ $\mathrm{dm}^{3}$ であるため，この直線性は全濃度領域にわた って維持されていると考えられる。またここに 示したホウ酸水溶液处理材の重量增加は，すでに 報告した結果 ${ }^{11,12)}$ とよい一致を示した。

一方，メ夕ノール溶液で処理した試験体も重量 増加はホウ素濃度とともに大きくなっているが, ここで注目すべき点は, 濃度 $1.1 \mathrm{~mol} / \mathrm{dm}^{3}$ のメ夕 ノール溶液で処理した試験体の重量増加が，飽和 濃度 $\left(8.8 \times 10^{-1} \mathrm{~mol} / \mathrm{dm}^{3}\right)$ の水溶液で処理した場 合よりも大きくなるであろうと予想されることで ある。つまり，風乾後のメタノール溶液処理スギ 材中のホウ素が，水溶液処理材中と同じ化学種と して存在すると仮定すれば，メ夕ノールを溶媒と して用いることにより飽和水溶液で処理するより も，より多量のホウ素を注入できることが示唆さ れているのである。また，ホウ酸の水に対する溶 解度は $30^{\circ} \mathrm{C}$ で約 $1.1 \mathrm{~mol} / \mathrm{dm}^{3}$ であるのに対し, メ夕 ノールでは $29^{\circ} \mathrm{C}$ で約 $3.7 \mathrm{~mol} / \mathrm{dm}^{3}$ である。つまり, 常温ではメタノールは水の 3 倍以上のホウ酸を溶 解することが期待される。したがって，本実験で 使用した最も高濃度のメタノール溶液は $1.1 \mathrm{~mol} /$ $\mathrm{dm}^{3}$ であるが，より高い濃度の溶液を調製するこ とも可能であり，水溶液に比べかなり多量のホウ 素を木材へ含浸することができると考えられる。

\section{2 ラマンスペクトル測定}

ホウ酸は純水に溶解するとごく一部が解離して $\mathrm{H}^{+}$と $\mathrm{B}(\mathrm{OH})_{4}$-になるが, 大部分は $\mathrm{B}(\mathrm{OH})_{3}$ の形で 溶存している $\left(\mathrm{B}(\mathrm{OH})_{3}+\mathrm{H}_{2} \mathrm{O} \rightarrow \mathrm{H}^{+}+\mathrm{B}(\mathrm{OH})_{4}{ }^{-}\right.$, $\left.\mathrm{p} K_{\mathrm{a}}=9.24\right)$ 。われわれは水溶液処理したスギ材中 のホウ素もそのほとんどがホウ酸 $\left(\mathrm{B}(\mathrm{OH})_{3}\right)$ と して存在していることを，ラマン分光法によって 確認し報告している11.123。ホウ酸やホウ酸塩の水 溶液における反応，溶存状態についてはNMRゃ ラマン分光法を用いた研究が多数行われてきてい る ${ }^{16-211}$ が，メタノール溶液中でホウ素がどのよう な化学状態にあるかを詳しく調べた研究は，われ われの知る限りではほとんど発表されていない。 しかしながら,一般にホウ酸とアルコール（ROH） 
は硫酸で脱水縮合することによりホウ酸エステル $\left(\mathrm{B}(\mathrm{OR})_{3}\right)$ が生成し，そのエステルはさらにアル コールと反応して $\mathrm{H}\left[\mathrm{B}(\mathrm{OR})_{4}\right]$ を生じるから，メ タノールに溶解したホウ酸は水溶液中とは全く異 なった化学種として存在していることが予想され る。化学分析としてはまだ予備的な段階であるが， ラマン測定では含浸処理に用いたホウ酸ーメ夕 ノール溶液中に $\mathrm{B}(\mathrm{OH})_{3}$ または $\mathrm{B}(\mathrm{OH})_{4}-$ に対応 するバンドは検出されず，この予想を支持する結 果が得られている。さらに, 各濃度のメタノール 溶液において, $\mathrm{B}\left(\mathrm{OCH}_{3}\right)_{3}$ に帰属されると考えら れるバンドが $730 \mathrm{~cm}^{-1}$ 付近に現れることも確認し ている。

したがって, 前述したように, ホウ素の含浸量 に関する正確な情報を得るためには，重量増加を 計るだけでなく，風乾・恒量化後の試験体中にあ るホウ素の状態分析を行い，どのような化学種と して木材中に存在するかを確認することが不可欠 であるといえる。

\subsection{1 処理材表面のラマンスペクトル}

$7.3 \times 10^{-1} \mathrm{~mol} / \mathrm{dm}^{3}$ のホウ酸ーメタノール溶液 を含浸し, 風乾・恒量化した後のスギ試験体表面 のラマンスペクトルを図 4 に示す。木口面，柾目 面, 板目面 (接線断面) の早材部について各々数 カ所測定を行ったが，同一断面内ではスペクトル の線形掞よび強度に測定位置よる顕著な変動は認 められなかった。なお, 対照のためホウ酸微結晶 と無処理スギ材木口面早材部のラマンスペクトル も併せて示してある。スギ辺材のラマンスペクト ルについては，われわれはこれまでに多数の報 告11,12,22-25)を行ってきたが, 本実験で得られたスぺ タトルもそれらとの間に有意の差はなかった。

いずれの断面でも $879 \mathrm{~cm}^{-1}$ (全対称伸縮振動 $v_{1}$ ) と $497 \mathrm{~cm}^{-1}\left(v_{2}\right)$ にホウ酸 $\left(\mathrm{B}(\mathrm{OH})_{3}\right)$ に特徵的な 鋭いラマンバンドが観測されており, 試験体表面 および表面近傍にはかなり多量のホウ酸が微結晶 として析出していることがわかる。なかでも木口 面ではホウ酸のラマンバンドがスギ材に対して最 も高い相対強度で観測されており, $1167 \mathrm{~cm}^{-1}\left(v_{3}\right)$ のバンドもスペクトル上に確認できるほどであ る。このことから，いったん試験体内部にまで浸 透したメタノール溶液が, 風乾時に繊維方向に沿 って木口へと移動したことが推察される。

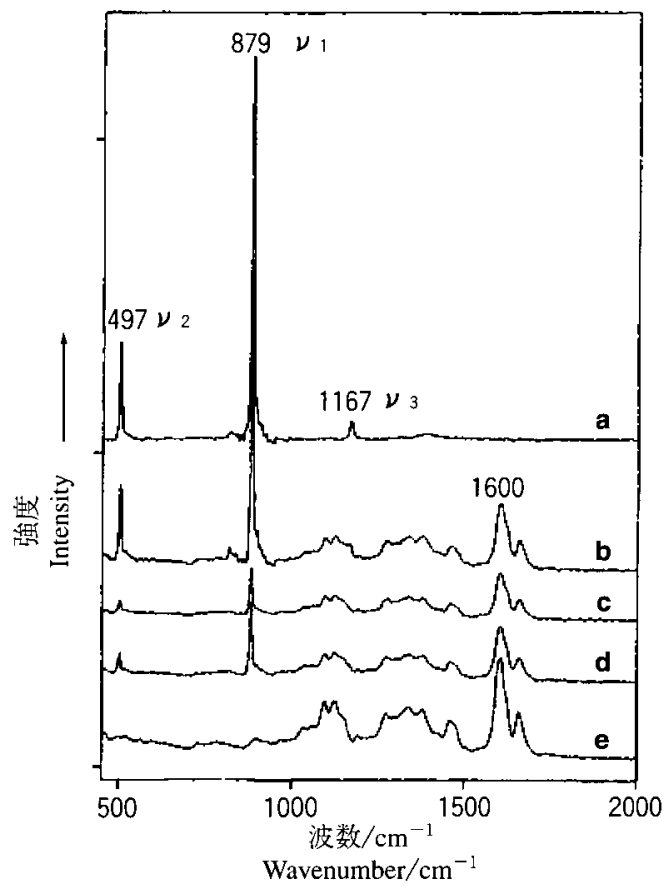

図 4 ホウ酸一メタノール溶液 $\left(7.3 \times 10^{-1} \mathrm{~mol} / \mathrm{dm}^{3}\right)$ で処理した試験体表面のラマンスペクトル

(a) ホウ酸 (微結晶),(b) 木口面,(c) 柾目面,

(d) 板目面, (e) 無好理試験体 (木口面)

Fig. 4 Raman spectra of surfaces of wood block treated with methanolic boric acid solution $\left(7.3 \times 10^{-1} \mathrm{~mol} / \mathrm{dm}^{3}\right)$

(a) boric acid (microcrystalline), (b) transverse sectional surface, (c) radial sectional surface, (d) tangential sectional surface, (e) control wood block (transverse sectional surface)

図4が示すもうひとつの重要な結果は, B $(\mathrm{OH})_{3}$ 以外のホウ素化合物に帰属されるラマンバ ンドがいずれの断面においても検出されなかった ことである。このことは風乾後の試験体表層では, メタノール中でエステル化したホウ酸が風乾時に 速やかに加水分解し，ホウ素の大部分が $\mathrm{B}(\mathrm{OH})_{3}$ として存在していること示唆している。なお，ホ ウ酸のラマンバンド強度は処理溶液の濃度ととも に減少したが，いずれのメタノール溶液で処理し た試験体でも，各断面のラマン測定において同様 の結果が得られた。

\subsection{2 処理材内部におけるホウ素分布}

次に試験体内部のホウ素分布と化学的状態に関 する情報を得るため, ホウ素濃度 $1.1 \mathrm{~mol} / \mathrm{dm}^{3} の メ$ タノール溶液で処理した試験体を柾目面と平行に 二等分に切断し，その切断面について絨維方向に 


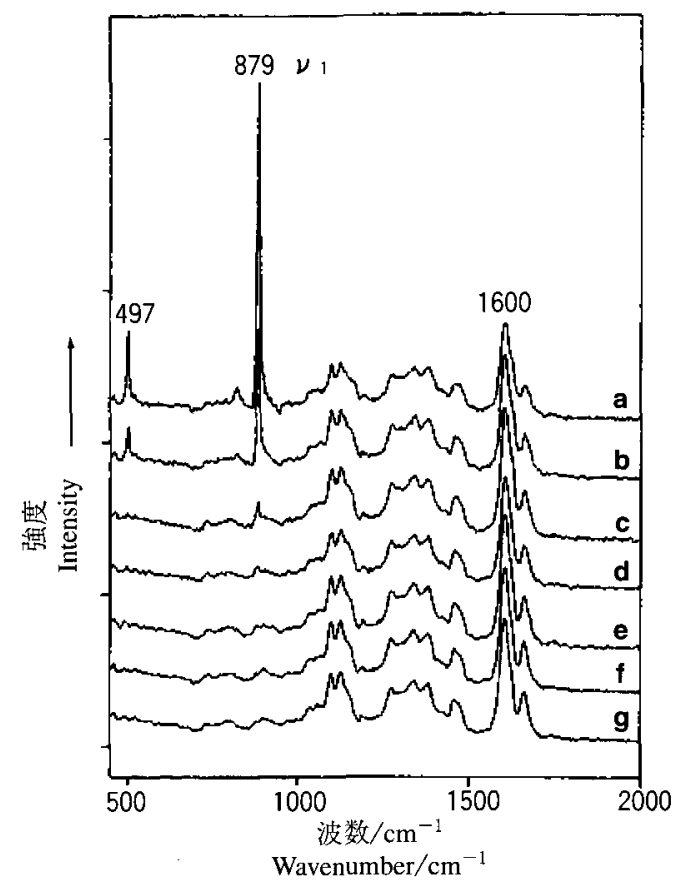

図 5 ホウ酸ーメタノール溶液 $\left(1.1 \mathrm{~mol} / \mathrm{dm}^{3}\right)$ で処 理した試験体切断面上繊維方向のラマンスペ クトル変化
(a) 木ロからの距離；0.5mm，(b)；1 mm，
(c) ; $2 \mathrm{~mm},(\mathrm{~d}) ; 3 \mathrm{~mm},(\theta) ; 5 \mathrm{~mm},(\mathrm{f}) ; 10 \mathrm{~mm}$,
(g) $; 25 \mathrm{~mm}$

Fig. 5 Line map of Raman spectra in the longitudinal direction of the cut surface of wood block treated with methanolic boric acid solution $\left(1.1 \mathrm{~mol} / \mathrm{dm}^{3}\right)$

(a) distance from an end grain; $0.5 \mathrm{~mm}$, (b) ; $1 \mathrm{~mm}$, (c); $2 \mathrm{~mm}$, (d) ; $3 \mathrm{~mm},(\mathrm{e})$; $5 \mathrm{~mm}$, (f) ; $10 \mathrm{~mm}$, (g) ; 25mm

沿って測定したラマンスペクトルを図 5 に示す。 木ロからの距離が最も短い $0.5 \mathrm{~mm}$ の測定点では きわめて強い $\mathrm{B}(\mathrm{OH})_{3}$ のラマンバンドが観測され ているが，その強度は距離の増加とともに急激に 減少して扔り，木口付近にホウ素が偏って存在し ていることが示されている。このようなホウ素の 偏在は水溶液処理材でも同様に観測されてい る12)。また，いずれのスペクトルでも $\mathrm{B}(\mathrm{OH})_{3}$ 以 外のホウ素化合物に帰属される振動バンドは検出 されておらず，このことから，風乾・調湿後のメ 夕ノール溶液処理材内部に含まれているホウ素 は，ほとんどすべてが $\mathrm{B}(\mathrm{OH})_{3}$ として存在するも のと予想される。

また，図 5 では試験体の内部に入り达むにつれ ホウ素量の急激な減少が現れているが，木口から の距離が最も長い $25 \mathrm{~mm}$ の測定点においても, 微

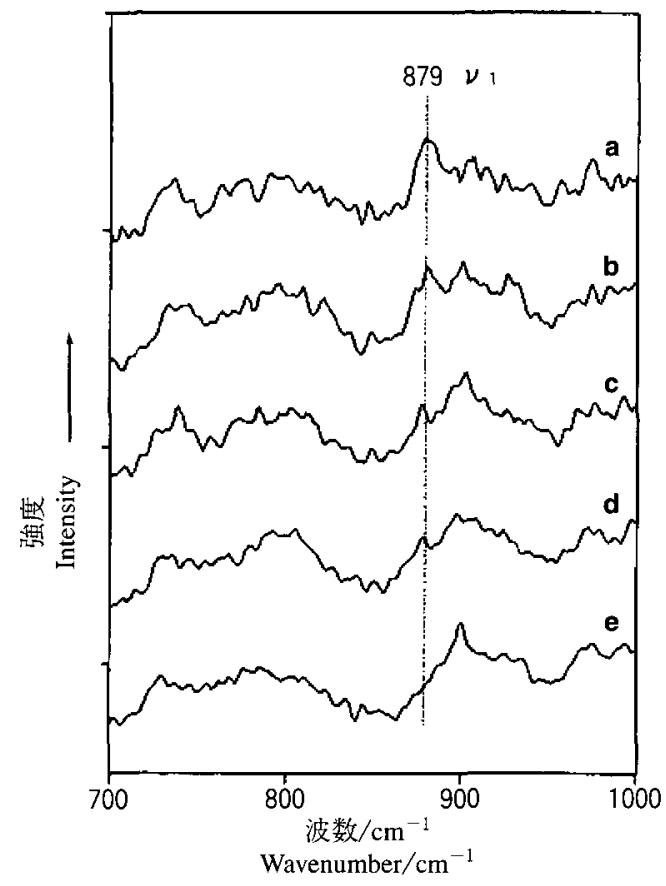

図 6 ホウ酸一メタノール溶液 $\left(1.1 \mathrm{~mol} / \mathrm{dm}^{3}\right)$ で処 理した試験体切断面上纎維方向のラマンスペ クトル变化 (波数領域700-1000 $\mathrm{cm}^{-1}$ )

(a) 木口からの距離； $3 \mathrm{~mm}$, (b) ; $5 \mathrm{~mm}$, (c) ; $10 \mathrm{~mm}$ ，(d)；25mm，(e)無処理試験体

Fig. 6 Line map of Raman spectra in the range from $700 \mathrm{~cm}^{-1}$ to $1,000 \mathrm{~cm}^{-1}$ in the longitudinal direction of the cut surface of wood block treated with methanolic boric acid solution $\left(1.1 \mathrm{~mol} / \mathrm{dm}^{3}\right.$ )

(a) distance from an end grain; $3 \mathrm{~mm}$, (b) ; $5 \mathrm{~mm}$, (c); $10 \mathrm{~mm}$, (d) ; 25mm, (e) control wood block

小ながら $v_{1}$ バンドがピークとして検出されてい るように見える。この点を確認するために、, $v_{1}$ 近傍 の波数領域を搪大したスペクトルを図 6 に示す。 未処理材と比較すると，明らかにいずれの距離に 抢いても $879 \mathrm{~cm}^{-1}$ の波数に る。このことは，いったんメタノール溶液が浸透 すれば木口からの距離が大きくとも，風乾後もあ る程度の量のホウ素が残っていることを示してい る。また，距離が数ミリメートル以上になるとv 強度減少の割合はきわめて小さくなり，特に10 $\mathrm{mm}$ 以上ではほとんど減少していないこともこの 分布の特徴である。

試験体内部で上記のようなホウ素の分布が起こ ることの解釈については，さらに詳細な検討が必 要であるが，いずれにしても本実験の方法で含 浸・風乾処理を行えば，ホウ素は表面および表面 
近傍にのみに濃縮すると考えられる。つまり，水 溶液, メ夕ノール溶液いずれを用いても，材内部 のホウ素濃度は含浸溶液濃度および重量の増加か ら期待するほどは上昇しない可能性が高いという ことになる。

\section{3 重量増加率の差異について}

最後にメタノール溶液処理した試験体が水溶液 処理材に比べ，重量増加率が低かったこと（図 3 参照）について考察する。すでに述べたように， 水溶液処理材と同様メ夕ノール溶液処理材でも, ラマン測定で検出されたホウ素はすべて $\mathrm{B}(\mathrm{OH})_{3}$ として存在していた。この結果から, 減圧処理中 にメタノール溶液のホウ素濃度が減少するか，ま たは風乾中に何らかのかたちで試験体外へホウ素 が放出されることが原因となって, 重量増加率が 低下したことが示唆される。しかしながら，減圧 処理に伴うメタノール溶液全体の減少率が $1 \%$ 末 満であることから考えて，前者の影響は大きくな いことが推定される。一方, 後者については, 液 体としてメタノール溶液が風乾中に試験体から流 出するような現象は，少なくとも肉眼では認めら れなかったが，ビーカー内でメタノール溶液処理 材を風乾した実験では, ビーカー内壁に白色粉末 状物質の付着が見られた。このことは風乾中にホ ウ素が揮発性化合物として試験体外へ放散された ことを示唆している。

ラマン測定の結果, この付着物質はホウ酸であ ることがわかったが，この放散が水溶液処理材に 比べてメタノール溶液で処理した試験体の重量増 加率が低下する主な原因であると考えられる。つ まり,メタノール溶液中でホウ素は常温でも蒸気 圧の高い化学種として存在し, その一部が風乾の 際に溶媒であるメタノールとともに気体として試 験体外一放出されるものと解釈される。低級の木 ウ酸エステル $\left(\mathrm{B}(\mathrm{OR})_{3}\right)$ は揮発性を有するため, もし少ない割合であっても $\mathrm{B}\left(\mathrm{OCH}_{3}\right)_{3}$ が生成し ていれば図3のメタノール処理材に関する結果を 説明できる。なお，いったんエステル化したホウ 素化合物は, 風乾よって溶媒であるメ夕ノールが 蒸発するとともに加水分解され， $\mathrm{B}(\mathrm{OH})_{3}$ に戻る ものと考えられる。

\section{4. 結言}

本実験におけるラマンスペクトル測定から，ホ ウ酸一メタノール溶液を用いて含浸処理したスギ 材中でのホウ素の化学的挙動と分布に関して, ホ ウ酸水溶液処理材との比較から以下の知見が得ら れた。

ホウ酸ーメタノール溶液として注入されたホウ 素は，一部が風乾時に揮発性の化合物として木材 から放散するが，大部分は風乾・調湿後 $\mathrm{B}(\mathrm{OH})_{3}$ として材内に留まる。したがって，水よりも高濃 度のホウ酸溶液を調製できるメタノールを溶媒と して用いることにより，総量としてょり多くのホ ウ素を木材中に容易に注入することができる。し かしながら, 注入後, 通常の風乾によってメ夕ノー ルを除去すれば，ホウ素は木材の表面および表層 に濃縮され，高濃度の溶液を用いても材内部の木 ウ素量は, 注入されたホウ素の総量から期待する ほど上昇しない可能性が高い。

以上のことはホウ酸ーメタノール溶液の注入 が，木材へのホウ素含浸法として実用化の可能性 を有していることを示しているとともに，ホウ素 を処理材内部により均一に分布させるための検討 が必要なことを示唆している。

\section{引用文献}

1) Cummins, J.E. : Recommendations for the commercial treatment of green veneer to render it immune from attack by the powder post beetle. Aust. Timber J , , 4, 661-667 (1938).

2 ) Spiller, D. and Denne, R.W. : The larval transfer method of determining toxicity of timber preservatives to Anobium punctatum De Geer. New Zealand J. Sci. Technol., 30, 129-139 (1948).

3 ) Murphy, R. J. , Barnes, H. M. and Gray S. M. : Decay and soil depletion studies with polymer/ boron preservative systems. Forest Products J., 45, 77-81 (1995).

4) Pizzi, A. and Baecker, A. : A new boron fixation mechanism for environment friendly wood preservatives. Holzforschung, 50, 507-510 (1996).

5 ) Thevenon M. F., Pizzi, A. and Haluk, J. P. : Non toxic albumin and soja protein borates as 
ground-contact wood preservatives.Holz RohWerkstoff, 55, 293-296 (1997).

6) Thevenon, M. F., Pizzi, A. and Haluk J. P. : Protein borates as non-toxic, long-term, widespectrum, ground-contact wood preservatives. Holzforschung, 52, 241-248 (1998).

7 ) Yalinkilic, M. K. , Imamura, Y., Takahashi, M. and Yalinkilic, A.C. : In situ polymerization of vinyl monomers during comprehensive deformation of wood treated with boric acid to decay boron leaching. Forest Products J. , 49, 43-51 (1999).

8 ) Toussaint-Dauvergne, E., Soulounganga, P. , G (rardin, P. and Loubinoux, B. : Glycerol/glyoxal : a new boron fixation system for wood preservation and dimensional stabilization. Holzforschung, 54, 123-126 (2000).

9）角田邦夫, Grace, J. K. , Byrne, T. and Morris, P.I.：地下シロアリおよび腐朽に対する八ホウ 酸二ナトリウム四水和物（ティンボア）処理家 屋土台の劣化防止効果, 木材学会誌, 48, 107114 (2002).

10) Byrne, T., Minchin, D. R., Morris, P. I. and 角田邦夫：湿潤コンクリート, 結露あるいは浸 水条件に暴露した場合の処理土台からのホウ酸 の溶脱，木材学会誌，48，115-121 (2002).

11）山内繁, 土居修一：ラマン分光法で視た木材 中のホウ酸一ホウ酸水溶液含浸処理後のスギ 材，木材保存，26，266-272 (2000).

12) Yamauchi, S. and Doi, S.: Raman spectroscopic study on the behavior of boric acid in wood. J. Wood Sci. , 49, 227-234 (2003).

13) Vinden, P. , Burton, R. J. and Bergervoet, A. J. : Vapour phase treatment of wood with trimethyl borate. Royal Soc. Chem ., 265-274 (1991).

14) Hashim, R. Murphy, R. J. , Dickinson, D. J. and Dinwoodie, J.M. : The physical properties of boards treated with vapor boron. Forest Products. $J$. , 47, 61-66 (1997).

15）古野毅, 後藤崇志, 加藤定信：ケイ酸塩一ホウ 素化合物系による木材無機質複合体の EPMA 観察と酸素指数法による難然性評価, 材料, 50, 383-390 (2001).
16) Smith, H.D. Ir. and Wiersema, R. J. : Boron-11 nuclear magnetic resonance study of polyborate ions in solution.Inorg.Chem., 11, 1152-1154 (1972).

17) Maya, L. : Identification of polyborates and fluoroborate ions in solution by Raman spectyroscopy. Inorg. Chem. , 15, 2179-2184 (1976).

18) Maeda, M. , Hirao, T., Kotaka, M. and Kakihana, H. : Raman spectra of polyborates ions in aqueous solution.J.Inorg. Nucl.Chem., 41, 1217-1220 (1979).

19) Adams, C. J. and Clark, I. E. : On the nature of the peroxoborate ion in solution. Polyhedron, 2, 673-675 (1983).

20) Salentine, C. G. : High-field 11B NMR of alkali borate/aqueous polyborate equilibria. Inorg. Chem., 22, 3920-3924 (1983).

21) Flanagan, J., Griffith, W. P. , Powell, R. D. and West, A.P. : Nature of peroxoborate species in aqueous solution/a study by boron-11 nuclear magnetic resonance and Raman spectroscopy. $J$. Chem.Soc. Dalton Trans. , 1651-1655 (1989).

22）山内繁，小泉章夫，栗本康司，田村靖夫：振 動分光法による木材および木質材料の研究（第 1 報) ラマン散乱测定による木材中の MDIの検 出, 日本接着学会誌, 32, 453-456 (1996).

23）山内繁，小泉章夫，栗本康司，田村靖夫：振 動分光法による木材および木質材料の研究（第 2 報）赤外分光法とラマン分光法から視た木材 に対するMDIの浸透挙動，日本接着学会誌， 33, 95-102 (1997).

24）山内繁，田村靖夫，栗本康司，小泉章夫：振 動分光法による木材および木質材料の研究（第 3 報）木材に含まれる接着剤の非破壊的識別法 としての FT-ラマン分光法, 日本接着学会誌,

33, 380-387 (1997).

25）山内繁，田村靖夫，栗本康司，小泉章夫：振 動分光法による木材および木質材料の研究（第 4 報）MDIの木材への浸透挙動に及ぼす希釈刘 の溶媒効果, 日本接着学会誌，35，300-308 (1999).

(2004.1.26受付) (2004. 3.11受理) 